\title{
The application of green building standards within the framework of comprehensive assessment of the former airport renovation in the city of Rostov-on-Don
}

\author{
Svetlana Sheina, Albina Fedorovskaya*, Eduard Tumanyan
}

Don State Technical University, Gagarin square 1, Rostov-on-Don, 344000, Russia

\begin{abstract}
The urgency of environmental technologies in the construction sector is evidenced by the current environmental conditions in the postindustrial period, the demand of the global community for the use of energy-saving technologies, underdevelopment, and existing development prospects of the relevant technologies in the Russian Federation. Article is devoted to application of green building standards of the former airport renovation in the Rostov-on-Don.
\end{abstract}

\section{Introduction}

Demand for qualified spatial planning and management of territory renovation exists currently within the framework of the renovation project of the former airport in Rostov-onDon.

The green building concept contributes to improving the quality of design, and therefore construction solutions that ensure environmental friendliness, energy efficiency, environmental conservation, and the comfort of everyday human activities [1,2]. A key factor in the implementation of the construction sector under the concepts of environmental conservation is the development of green building standards, namely STO NOSTROY 2.35.4-2011 (STO NOSTROY - National Association of Civil Engineers Industry Standards) [3].

A comprehensive territory assessment, serving as the basis of a highly effective spatial planning approach, allows for giving consideration to environmental sustainability that is particularly relevant for the renovation of the airport territory. The said is an essential condition that stems from long-term usage of the said territory as an industrial facility.

\section{Methods}

Comprehensive territory assessment involves an integrated approach to the analysis of the territorial location and qualitative features of all types of resources [4]. Comprehensive

\footnotetext{
* Corresponding author: bina-87@mail.ru
} 
territory assessment is aimed at an extensive analysis of the territory by a variety of factors impacting the efficiency of its use. Territory assessment involves a range of options that have social, economic, spatial, and environmental features in common. Comprehensive territory assessment methods are based on cadastral valuation principles [5]. Consequently, the required criteria for settlement territories assessment are adopted from cadastral valuation methodology (comprehensive value zoning method) that meets the requirements of the comprehensive territory assessment. Relative territory value factors and the evaluation scores for the same are given in Table 1 [6].

Table 1. Relevant assessment factors for populated territories

\begin{tabular}{|r|c|c|}
\hline \multicolumn{1}{|l|}{ No. } & Relative value factors & Score \\
\hline 1 & $\begin{array}{c}\text { Availability of social and business, and } \\
\text { administrative center }\end{array}$ & $0 \ldots 1$ \\
\hline 2 & $\begin{array}{c}\text { Level of engineer facilities (utility services, } \\
\text { transport }\end{array}$ & $0 \ldots 1$ \\
\hline 3 & Level of community services development & $0 \ldots 1$ \\
\hline 4 & Availability of heritage sites & $0 \ldots 1$ \\
\hline 5 & Environmental status & $0 \ldots 1$ \\
\hline 6 & $\begin{array}{c}\text { Engineering and geological conditions } \\
\text { impacting construction }\end{array}$ & $0 \ldots 1$ \\
\hline 7 & \begin{tabular}{c} 
Landscape and recreational conditions \\
\hline
\end{tabular}
\end{tabular}

The foregoing factors are standard and universal and do not allow for an in-depth and impartial assessment of the plot location in a locality within the framework of the renovation of the former airport territory that is to meet the requirements of the implementation of the sustainable development concept. This article puts forward the performance of a comprehensive territory assessment with regard to a number of environmental sustainability factors under the sustainable building standard "STO NOSTROY 2.35.4-2011". The basic principle of the said standard is the sustainability of the ecosystem that consists in the elimination of a negative impact on the Earth's ecosystem for the purpose of meeting the ecosystem needs, which therefore maintains the possibility of sustainable development for future generations

The said standard presents a comprehensive approach and takes a variety of categories and criteria for environmental sustainability into account (Fig.1). 


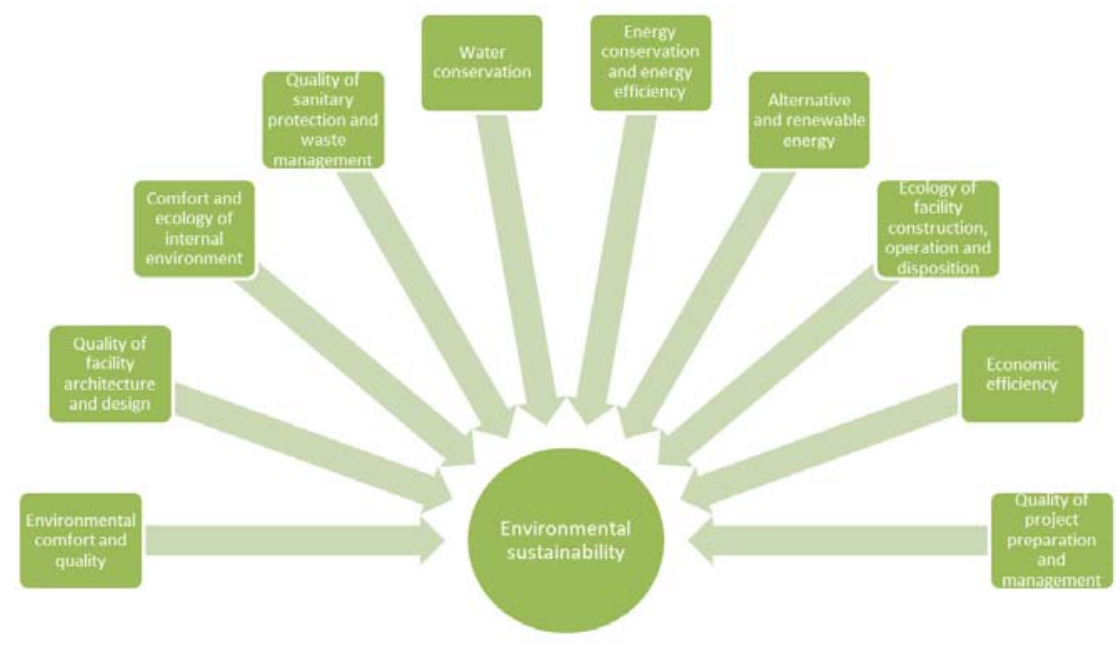

Fig. 1. Environmental sustainability criteria

The system can be applied to all categories of residential and specific categories of public buildings throughout the life cycle.

Let us consider the possibility of a comprehensive territory assessment under the adjusted factors adopted from STO NOSTROY 2.35.4-2011. For the purpose of reliable assessment of the adjusted factors, the scoring system was transformed into a form similar to the scoring system of a standard comprehensive assessment by means of interpolation. The adjusted factors of a comprehensive territory assessment and features of the same are given in Table 2.

Table 2. Adjusted factors of comprehensive territory assessment and features thereof

\begin{tabular}{|c|c|c|c|c|}
\hline No. & Factor & Indicator & Parameters & Score \\
\hline \multirow[b]{2}{*}{1} & \multirow[b]{2}{*}{$\begin{array}{r}\text { Proximity of } \\
\text { water environment }\end{array}$} & \multirow{2}{*}{$\begin{array}{l}\text { Presence of } \\
\text { unswamped natural } \\
\text { water bodies at the } \\
\text { distance of, } m\end{array}$} & $30-300$ & 1 \\
\hline & & & $301-500$ & 0,5 \\
\hline \multirow{3}{*}{2} & \multirow{3}{*}{$\begin{array}{c}\text { Proximity of } \\
\text { water environment* }\end{array}$} & \multirow{3}{*}{$\begin{array}{l}\text { Presence of } \\
\text { artificial water bodies } \\
\text { in residential building } \\
\text { adjacent territory: }\end{array}$} & $\begin{array}{l}\text { Outdoor } \\
\text { pool }\end{array}$ & 0,3 \\
\hline & & & $\begin{array}{c}\text { Artificial } \\
\text { pond with water } \\
\text { from utility } \\
\text { mains }\end{array}$ & 0,6 \\
\hline & & & $\begin{array}{c}\text { Fountain, } \\
\text { decorative water } \\
\text { bodies (waterfall) }\end{array}$ & 1 \\
\hline \multirow{2}{*}{3} & \multirow{2}{*}{ Visual comfort } & \multirow{2}{*}{ Expert assessment } & satisfactory & 0,3 \\
\hline & & & good & 0,6 \\
\hline
\end{tabular}




\begin{tabular}{|c|c|c|c|c|}
\hline & & & excellent & 1 \\
\hline & \multicolumn{4}{|c|}{$\begin{array}{l}\text { Parameter estimation: by subjective assessment of absence of monotonous } \\
\text { scenery, facades, roofs, windows, interiors. }\end{array}$} \\
\hline \multirow{4}{*}{4} & \multirow{3}{*}{$\begin{array}{l}\text { Insolation of } \\
\text { adjacent territory }\end{array}$} & \multirow{3}{*}{$\begin{array}{c}\text { Availability } \\
\text { percent as per the } \\
\text { current standards, \% }\end{array}$} & $\begin{array}{l}\text { More than } \\
120\end{array}$ & 1 \\
\hline & & & $111-120$ & 0,6 \\
\hline & & & $105-110$ & 0,3 \\
\hline & \multicolumn{4}{|c|}{$\begin{array}{l}\text { Regulatory framework for the parameter: SanPiN2.2.1/2.1.1.1076; } \\
\text { SanPiN2.1.2.2645; CП 52.13330. }\end{array}$} \\
\hline \multirow[t]{2}{*}{5} & $\begin{array}{c}\text { Noise and } \\
\text { infrasound insulation } \\
\text { of residential building } \\
\text { adjacent territory }\end{array}$ & \multicolumn{2}{|c|}{$\begin{array}{l}\text { Territory analysis in ArcGIS ESRI } \\
\text { environment }\end{array}$} & $0 \ldots 1$ \\
\hline & $\begin{array}{r}\text { Regulatory } \\
\text { 30.03.1999; SP 51.1 }\end{array}$ & $\begin{array}{l}\text { mework for the paramete } \\
\text { 330; SanPiN2.1.2.2645; } C\end{array}$ & $\begin{array}{l}\text { cal Law No. } \\
2.1 .003 ; \mathrm{MC}\end{array}$ & d. 97. \\
\hline \multirow{4}{*}{6} & \multirow{3}{*}{$\begin{array}{l}\text { Availability of } \\
\text { parking slots }\end{array}$} & \multirow{3}{*}{$\begin{array}{c}\text { Number of } \\
\text { personnel per } 1 \text { parking } \\
\text { slot, no more than, } \\
\text { person per parking slot }\end{array}$} & 3 & 1 \\
\hline & & & 5 & 0,6 \\
\hline & & & 7 & 0,3 \\
\hline & \multicolumn{4}{|c|}{$\begin{array}{l}\text { Regulatory framework for the parameter: SP42.13330; SP54.13330; } \\
\text { SP118.13330. }\end{array}$} \\
\hline \multirow{4}{*}{7} & \multirow{3}{*}{$\begin{array}{l}\text { Green areas } \\
\text { availability }\end{array}$} & \multirow{3}{*}{$\begin{array}{l}\text { The ratio of green } \\
\text { adjacent territory to the } \\
\text { total area of the } \\
\text { adjacent territory, } \%\end{array}$} & $\begin{array}{l}\text { More than } \\
15\end{array}$ & 1 \\
\hline & & & $11-15$ & 0,6 \\
\hline & & & $5-10$ & 0,3 \\
\hline & Reg & ory framework for the $p$ & r: SP42.133 & \\
\hline
\end{tabular}

An essential aspect of the integrated territory development is the availability and condition of social infrastructure facilities [7]. Social infrastructure facilities are as follows:

- Education and science facilities

- Culture and art facilities

- Physical training and sport facilities

- Health facilities

- Other facilities

A key stage in the implementation of a comprehensive development project is the analysis of the social infrastructure conditions. Social infrastructure is a crucial component of comprehensive and sustainable territory development that provides the required level of living standards.

The territory under renovation is a former industrial area; consequently, social infrastructure facilities are currently absent.[8]. Based on the insufficient availability of social infrastructure facilities, the territory renovation project should be primarily focused 
on planning of the location of relevant facilities. The urban planning standards of the Rostov-on-Don city district set limit values of estimate indicators of spatial planning for each type of social infrastructure facilities that characterize the minimum availability level and the maximum territorial accessibility level.

\section{Results section}

Presently, a renovation project for the former airport has been developed by the company "Kortros", the spatial planning of which also provides for optimal location of infrastructure facilities and meets the requirements of the possibility of optimal placement of social infrastructure and meets the requirements of urban planning standards (Fig.2).

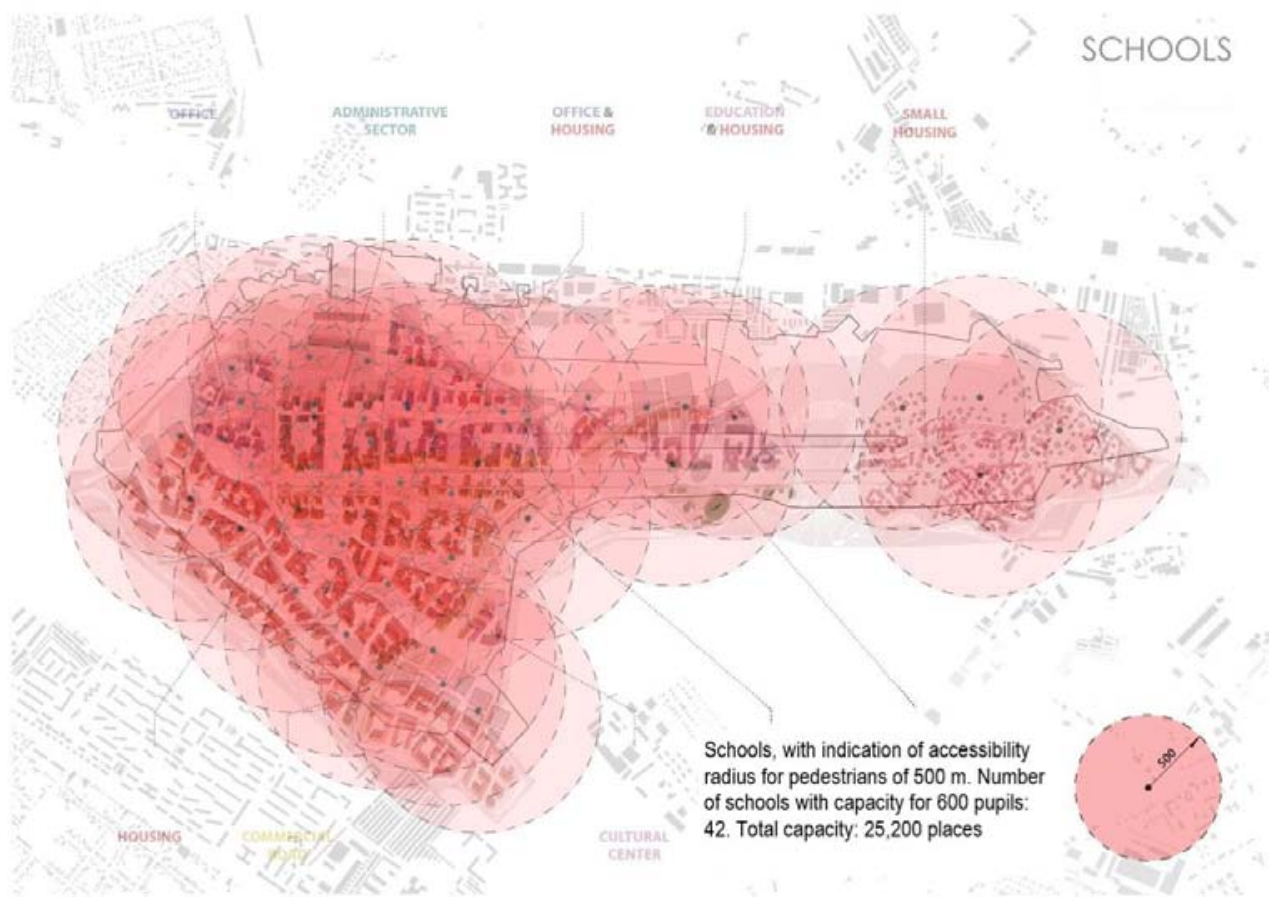

Fig. 2. Availability of educational institutions in the territory

A section of the territory of the former airport under renovation is selected from the existing project as an example of solution of the current task: assessment of social infrastructure facility (institution of general education) location (see Fig. 3). 


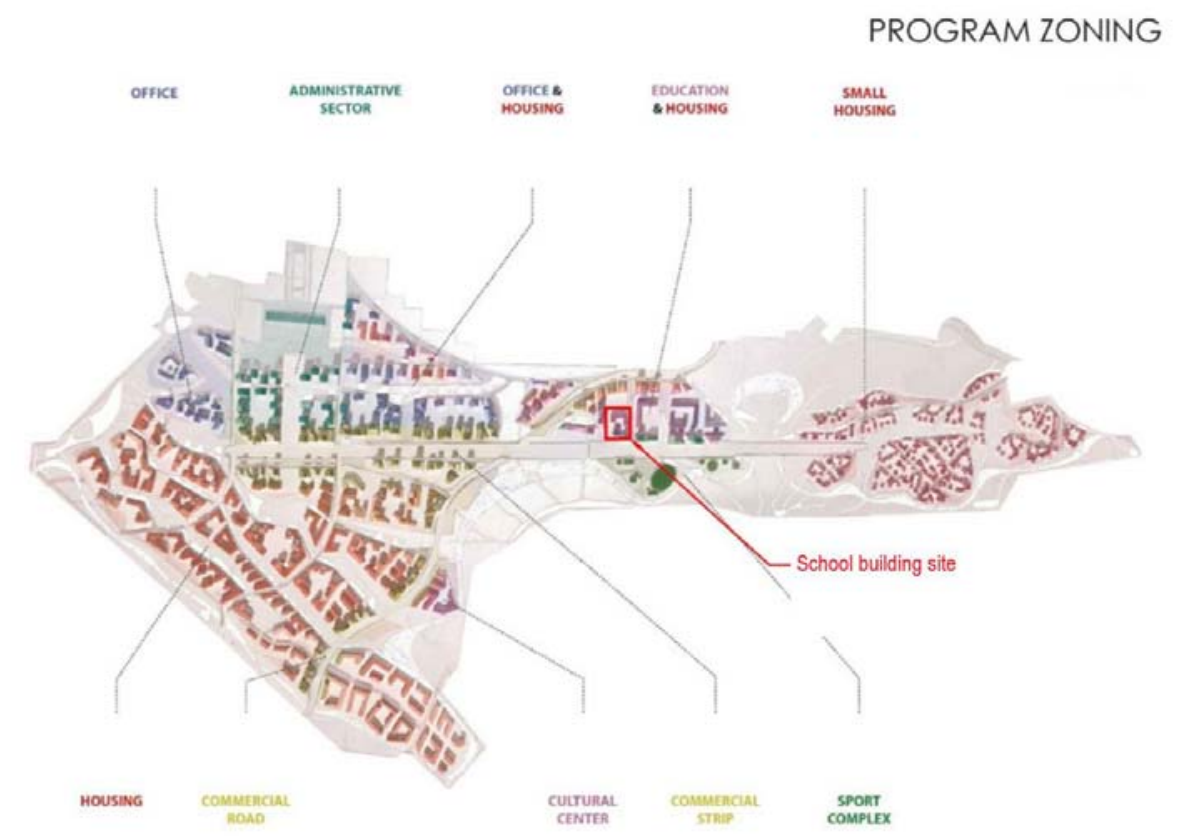

Fig. 3. Proposed location of a general education institution

Implementation of a comprehensive territory assessment shall be carried out with the use of modern geographic information technology, taking into account the factors of the adjusted comprehensive territory assessment. Modern geographic information technologies such as ArcGIS ESRI have the feature of analyzing the data characteristic of the territory by various parameters, to assess the territory, and display it in an interactive form [9].

For illustrative purposes, we shall carry out a comprehensive assessment of the territory of the former Rostov-on-Don airport under renovation by several factors with the use of ArcGIS ESRI software.

Let us take the factor of environmental conditions as an example of the comprehensive territory assessment results which depends on the number of negative factors reducing the value of land and the level of its suitability for various purposes. The factors affecting the final assessment include air pollution, site contamination, water pollution, electromagnetic fields, radiation, exceeding the value of permissible noise levels, and climatic conditions. Based on the results of the comprehensive territory assessment in the ArcGIS ESRI environment, the environmental assessment map of the site has been created (Fig. 4). The final score of the site environmental factor was 0.3 points, satisfactory. 


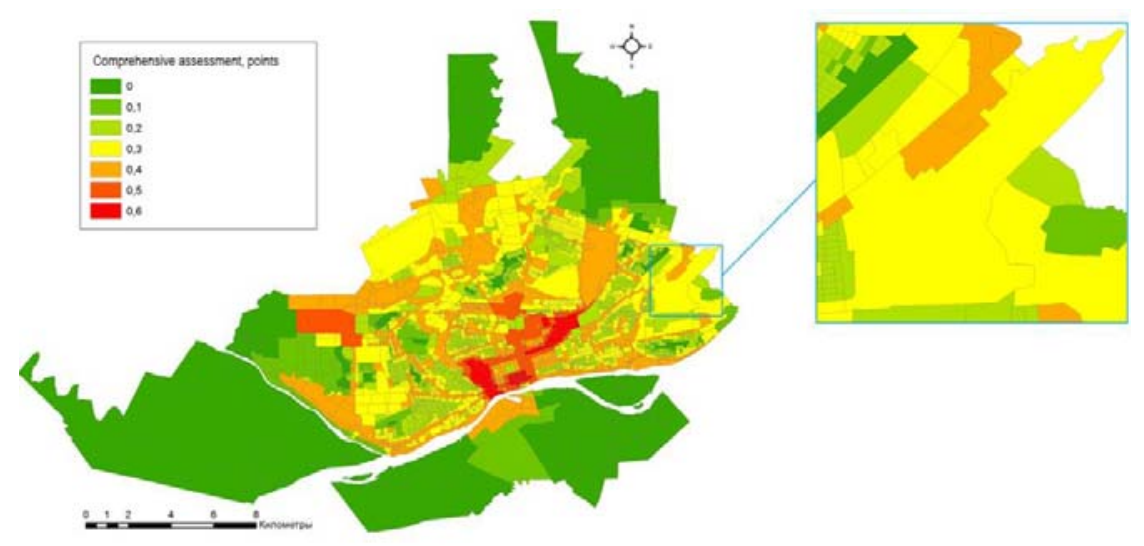

Fig. 4. Proposed location of a general education institution

The results of the comprehensive territory assessment revealed that the environmental situation failed to meet the requirements to a comfortable urban environment and the basic principles of sustainable development of territories. The necessary condition for the development of this territory is the implementation of activities that can have a positive impact on the environment [9]. For the existing territory, the main urban planning and environmental recommendations are as follows (see Table 3)

Table 3. Key environmental measures

\begin{tabular}{|l|c|}
\hline \multicolumn{2}{|c|}{ Key environmental measures } \\
\hline 1. & Establishment of safe environment in the residential development area; \\
\hline 2. & $\begin{array}{c}\text { Reduction of noise discomfort zones of in residential and public areas, } \\
\text { recreational and common use areas; }\end{array}$ \\
\hline 3. & Reduction of the noise pollution areas of in the areas near thoroughfares; \\
\hline 4. & $\begin{array}{c}\text { Creation of favorable microclimatic conditions in the residential development } \\
\text { areas and public areas; }\end{array}$ \\
\hline 5. & $\begin{array}{c}\text { Dense development acting as a barrier preventing the spread of noise and } \\
\text { harmful impurities along the main thoroughfares of the city; }\end{array}$ \\
\hline 6. & $\begin{array}{c}\text { Arrangement of green shelter belts along thoroughfares and other mains, } \\
\text { resistant to the influence of man-caused loads; }\end{array}$ \\
\hline 7. & Construction of noise-protection buildings and screens along city thoroughfares; \\
\hline 8. & $\begin{array}{c}\text { Increase of the green spaces area through non-standard methods (container } \\
\text { gardening, vertical gardening, etc.); }\end{array}$ \\
\hline 9. & Increase of water planes surface (ponds, fountains, pools); \\
\hline 10. & $\begin{array}{c}\text { Relieving the intra-district streets and passages from external traffic, creation of } \\
\text { a network of transition zones and boulevards; }\end{array}$ \\
\hline 11. & Protection of residential development from overcooling and exposure to wind; \\
\hline 12. & Ensuring an inflow of fresh air into the central and middle districts of the city; \\
\hline 13. & Liquidation of environmental risk zones threatening the safety and health of \\
\hline 14. & Improvement of natural and environmental frame of the residential area; \\
\hline 15. & Arrangement of protection against wind for residential development by means
\end{tabular}




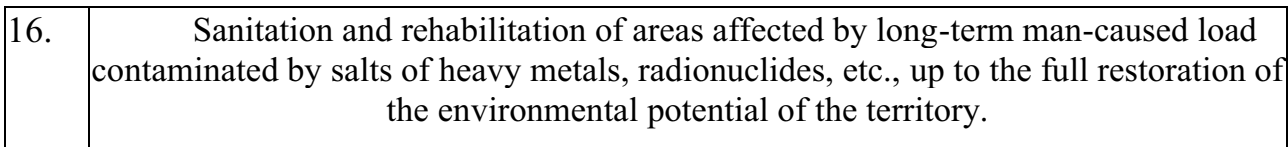

Selection and implementation of a set of urban planning and environmental measures are necessary for a complete analysis of the territory, as well as for possible prediction of its further use and definition of planning solutions, taking into account the natural environment and the models of impact on the urban area.

Pursuant to the methodology developed for the adjusted comprehensive territory assessment, we shall give an analysis of the factor "Proximity of water environment" as an example. According to the recommendations of NOSTROY 2.35.4-2011 industry standard, the said factor is evaluated by the presence of unswamped natural water bodies. Assessment differentiation depends on the remoteness of the corresponding aquatic environment:

30-300m - 1 point;

$301-500 \mathrm{~m}-0,5$ point;

over $500 \mathrm{~m}-0$ points.

By drawing a circle with a radius of $500 \mathrm{~m}$ around the area under assessment, with the use of the Yandex.Maps service and Autocad software, in accordance with the scale of the map, we can see that no unswamped natural water bodies exist in the area under assessment. According to the developed methodology of the adjusted comprehensive territory assessment, the score by this factor is 0 points due to the lack of unswamped natural water bodies.

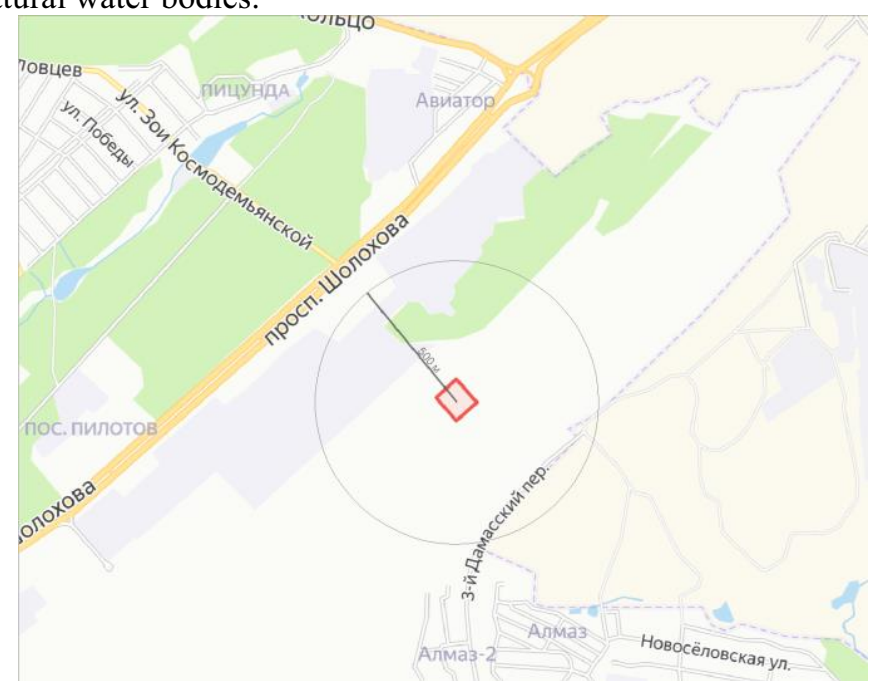

Fig. 5. Proposed location of a general education institution

Based on the results of the adjusted comprehensive assessment, we can observe that the measures to improve the environmental situation proposed earlier are particularly relevant for this area. An increase in the area of water surfaces can partially compensate for the lack of natural water bodies.

\section{Conclusions}

Pursuant to the requirements of regulatory documentation and the results of the comprehensive territory assessment, based on the totality of all its factors, the given site meets the requirements of the possibility to accommodate a general education institution. 
Renovation of such large industrial area is one of the most important tasks of spatial planning in the city of Rostov-on-Don. The territory under consideration needs a comprehensive development that provides optimal functional zoning and meets all the needs of a modern city. The basis of comprehensive development of the territory is the availability of social infrastructure facilities within the said territory. The developed method of comprehensive territory assessment has been adapted in accordance with the basic principles of sustainable development and is a fully operational tool for spatial planning of the city. Information capacity of the method is ensured by the use of ArcGIS ESRI interactive geoinformation technologies. Compliance with the principles of sustainable development has been achieved by the introduction of adjusted comprehensive territory assessment factors developed on the basis of the rating system for assessment of the sustainability of habitat as per NOSTROY 2.35.4-2011 industry standard. The developed method of the comprehensive assessment sufficiently reflects the possibility of territory development in accordance with the basic principles of sustainable development.

\section{References}

1. R. Komurlu, D. Arditi, A.P. Gurgun, Energy and Buildings. 90. 156-165 (2015)

2. N.I. Vatin, D.V. Nemova, D.S. Tarasova, A.A. Staritcyna, Advanced Materials Research 1065, 2669-2673 (2017)

3. S.G. Sheina, M.V. Panasenko, A.A. Fedorovskaya, IOP Conference Series: Materials Science and Engineering, 913(3), 032072 (2020)

4. S.G. Sheina, A.A. Fedorovskaya, E.G. Zaika, Vestnik Tomskogo gosudarstvennogo arkhitekturno-stroitel'nogo universiteta. JOURNAL of Construction and Architecture. 2, 207-215 (2018)

5. S. Sheina, L. Babenko, Advanced Materials Research 1044-1045, 1517 (2014)

6. N.G. Ovchinnikova, MATEC Web of Conferences 106, 01004 (2017)

7. I. L. Kievskiy, L.V. Kievskiy, International Journal of Applied Engineering Research. 10, 40893-40898 (2015)

8. M.A. Zolotykh, StudArctic Forum 2 (6), 33-46 (2017)

9. E.V. Sherbina, N.V. Danilina, D.N. Vlasov, International Journal of Applied Engineering Research 22(10), 43131-43138 (2015)

10. I.Y. Zilberova, Materials Science Forum 931, 834-839 (2018) 